\title{
CAMINHOS TRANCADOS (?): CONFLITOS E PROJETOS POLÍTICOS AFRO-RELIGIOSOS E O PROCESSO ELEITORAL NO RIO GRANDE DO SUL
}

\author{
Daniel Francisco de Bem ${ }^{1}$ \\ Rodrigo Marques Leistner ${ }^{2}$
}

\begin{abstract}
Resumo: Este artigo examina os problemas de inserção política concernentes às religiões afro-brasileiras no Rio Grande do Sul, visando compreender as razóes do fracasso eleitoral dos candidatos a cargos públicos oriundos destas religiosidades. Após algumas consideraçóes sobre o histórico das candidaturas originárias do campo afro-religioso, analisa-se o processo de construção dos empreendimentos eleitorais de dois líderes africanistas gaúchos nas eleiçóes 2010. A partir de então buscamos articular o entendimento da existência de obstáculos externos e internos à inserção política afro-religiosa com as estratégias eleitorais e discursivas dos candidatos afro-religiosos, no intuito de compreender como que na prática esses obstáculos influem nas estratégias e, possivelmente, na votação de cada candidato, assim de estabelecer algumas consideraçóes sobre o futuro do projeto político afro-religioso no estado do Rio Grande do Sul.
\end{abstract}

Palavras-chave: religiōes afro-brasileiras; campo religioso brasileiro e campo político brasileiro; processo eleitoral.

Abstract: This paper examines the political insertion of African-Brazilian religions in the state of Rio Grande do Sul (Brazil) in search of the reasons for the failure of candidates from this religion in the election for public offices. After some considerations on the history of candidacies representing the African-religious field, we analyze the choices made by two candidates in 2010 elections. We examine external and internal barriers to the political articulation within the African-religious group and the discourses and the electoral strategies of the candidates, in order to understand how these obstacles influence the strategies and potential voting on each candidate. We make some considerations about the future of the political representation of African-Brazilian religion followers at state of Rio Grande do Sul.

Keywords: African-Brazilian religions; Brazilian religious field; Brazilian political field; elections.

${ }^{1}$ Doutorando pelo Programa de Pós-Graduação em Antropologia Social - UFRGS. Pesquisador associado ao NER/PPGAS/UFRGS. Endereço Eletrônico: danielfranciscodebem@yahoo.com.br

${ }^{2}$ Doutorando pelo Programa de Pós-Graduação em Ciências Sociais - UNISINOS. Endereço Eletrônico: rodrigoless@yahoo.com.br

Debates do NER, Porto Alegre, ano il, N. I8, P. I29-I48, JUl./Dez. 20 IO 